\title{
PROBLEM JASNOŚCI W JĘZYKU PRAWNYM - ASPEKTY LINGWISTYCZNE I TEORETYCZNOPRAWNE
}

\author{
MARTA ANDRUSZKIEWICZ \\ Katedra Teorii Prawa i Etyki Prawa \\ Uniwersytet w Białymstoku \\ andruszkiewicz@uwb.edu.pl
}

\begin{abstract}
Abstrakt: Przedmiotem artykułu jest zagadnienie jasności rozważane w perspektywie lingwistycznej i teoretycznoprawnej. Jasność, obok komunikatywności i adekwatności, należy do pożądanych cech tekstu prawnego. Nakaz ich osiągania jest sformułowany w normatywnych regulacjach dotyczących zasad techniki prawodawczej, jak też stanowi składnik konstytucyjnej zasady prawidłowej legislacji. Jasność jest cechą tekstów prawnych wymaganą ze względu na redakcyjną poprawność $\mathrm{w}$ tworzeniu tekstu prawnego. Wynika $\mathrm{z}$ reguł tworzenia prawa zgodnie z zasadami państwa prawa. Postulat osiągania przez prawodawcę pożądanych cech tekstu prawnego ma charakter zarówno formalny, jak i etyczny. Jasność tekstu prawnego jest bowiem nie tylko właściwością konstrukcyjną, ale gwarantem w osiąganiu wartości, takich jak pewność prawa, bezpieczeństwo prawne obywateli, zaufanie do państwa i prawa. Problemem jest jednak to, że zrealizowanie postulatu jasności nie zawsze jest możliwe.
\end{abstract}


Celem przedstawionej analizy jest zbadanie przyczyn uzasadniających to, że wymóg jasności tekstu prawnego jest problematyczny i trudny do osiągnięcia. Wynika to z faktu, iż jest on uwarunkowany nie tylko przez czynniki stricte prawne, ale językowe, kontekstowe i etyczne.

Słowa kluczowe: dyskurs prawny, jasność tekstu prawnego, państwo prawa, technika prawodawcza

\title{
THE ISSUE OF CLARITY IN LEGAL LANGUAGE - LINGUISTIC AND THEORETICAL-LEGAL ASPECTS
}

\begin{abstract}
The aim of this article is to present the notion of clarity as considered from the linguistic and theoretical-legal perspectives. Clarity, similarly to communicativeness and adequacy, constitutes a desirable feature of any legal text. The necessity of considering the three features has been formulated in normative regulations regarding the tenets of a legislative technique. Furthermore, the requirement is part of a constitutional principle of proper legislation. Clarity characterizes legal texts; it is required due to the editorial correctness which should be achieved in the process of the writing of a legal text. It arises from the rules for making laws according to the principles of state under the rule of law. The requirement for the consideration of the desirable features of a legal text by a legislator has both formal and ethical dimensions, because the clarity of a legal text not only constitutes a structural property but also guarantees that values such as legal certainty, legal security of citizens as well as trust in both state and law are recognised. The point is, however, that it is not always possible to achieve such clarity.

The objective of this analysis is to investigate the causes which confirm that the requirement for the clarity of any legal text is complicated and not easy to meet. It is due to the fact that the requirement is conditioned not only by strictly legal factors but also linguistic, contextual as well as ethical ones.
\end{abstract}

Key Words: legal discourse, clarity in legal language, rule of law, legislative technique 


\section{Wprowadzenie}

Jasność zgodnie ze znaczeniem słownikowym jest definiowana jako zrozumiałość, brak zawiłości, precyzja, prostota (Szymczak 1978: 826), a także jednoznaczność i wyrazistość w sposobie wyrażania się ${ }^{1}$. Jest warunkiem poprawnego i sprawnego komunikowania się zgodnie $\mathrm{z}$ normą językową. Na gruncie językoznawczym jasność jest przedmiotem badania kultury języka, tekstologii, translatoryki i pragmatyki językowej. W prawoznawstwie jasność w odniesieniu do tekstu prawnego rozumiana jest jako wyznaczanie przez prawo precyzyjnych wzorów postępowania (jednoznaczność) oraz zrozumiałość (co najmniej komunikatywność) dla szerokiego grona adresatów (Wronkowska 1976: 20). Zarówno w świetle reguł językowych, jak i prawnych, jasność tekstu może być osiągana poprzez jednoczesne dążenie do precyzji i zrozumiałości. Prawne znaczenie omawianego pojęcia odwołuje się ponadto do konstytucyjnej zasady należytej legislacji. $Z$ tej zasady i wpisanego $\mathrm{w}$ jej treść postulatu jasności można wywodzić konstytucyjne prawo jednostki i obywatela do dobrej legislacji (Andruszkiewicz: 2016: 188). Jasność znajduje uzasadnienie nie tylko $\mathrm{w}$ normie językowej, ale normach konstytucyjnych, znajduje również odniesienie w dyrektywach prawidłowej legislacji oraz orzecznictwie Trybunału Konstytucyjnego. Trybunał wielokrotnie podkreślał, że postulat osiągania dostatecznej określoności przepisów prawa wchodzi w skład zasady demokratycznego państwa prawnego (wyrażonej w art. 2 Konstytucji RP) i wynikającego z niej nakazu przestrzegania reguł przyzwoitej (prawidłowej) legislacji (Wyroki TK z 13 kwietnia 1999 r., K 36/98; 10 kwietnia 2006 r., SK 30/0; 18 lutego 2004 r., P 21/02).

Tak rozumiany wymóg jasności jest nacechowany aksjologicznie. Dotyczy obowiązku zachowania reguł poprawności w tworzeniu prawa, a przez to zapewniania jego pewności, przewidywalności, skuteczności, zaufania obywateli do państwa i prawa, jawności, a także podmiotowego traktowania adresata. Podkreśla się, że redaktor tekstu prawnego powinien nie tylko przestrzegać zasad techniki prawodawczej, ale też wykazywać

${ }^{1}$ http://sjp.pwn.pl/szukaj/jasność.html. 
poszanowanie dla odbiorcy (Wronkowska 2007: 22). Dążenie do jasności ma charakter moralnego obowiązku, jest kwestią rzetelności i sumienia samego prawodawcy (Fuller 35-36). Znaną wśród prawników alegorią uzasadniającą etyczne aspekty formalnej strony tworzenia prawa jest opisywany przez Lona L. Fullera przypadek króla Rexa, któremu nie powiodło się stworzenie i utrzymanie systemu prawa, ponieważ nie realizował on koniecznych właściwości dobrego prawa, określanych jako warunki tzw. wewnętrznej moralności prawa (Fuller 2004: 27-31). Jednym $\mathrm{z}$ błędów popełnionych podczas sprawowania władzy i budowania porządku prawnego przez Rexa było tworzenie prawa niezrozumiałego. Przykład ten przekonuje, że system prawa nie może być skuteczny ani możliwy do utrzymania, jeżeli zabraknie mu fundamentalnych właściwości, do których należy zrozumiałość i jasność treści prawa, obok takich warunków jak promulgacja, możliwość spełnienia, niesprzeczność, nieretroaktywność $\mathrm{i}$ inne (Ibidem: $35 \mathrm{i}$ n., passim). Tym samym jasność prawa jest warunkiem jego jakości i jednym z najważniejszych składników praworządności, a nierealizowanie go przez prawodawcę może spowodować, że staje się ona nieosiągalna (Fuller 2004: 53).

\section{Jasność jako precyzja i zrozumiałość}

Normatywne wskazówki dotyczące techniki procesu tworzenia prawa zawarte są w Rozporządzeniu Prezesa Rady Ministrów z 20 czerwca 2002 r. w sprawie „Zasad techniki prawodawczej” (Dz. U. Nr 100, poz. 908 z późn. zm.), określane dalej jako ZTP). Oczekiwanie od nadawcy tekstu prawnego ich realizowania wynika $\mathrm{z}$ reguł technicznych, określających prawidłową praktykę redagowania tekstów prawnych i właściwego wyrażania merytorycznych treści prawa. W doktrynie i praktyce prawniczej przyjmuje się, iż wypowiedzi prawodawcy powinny być zgodne $\mathrm{z}$ regułami językowymi i logicznymi, co ma świadczyć o poprawności w tworzeniu przepisów. Zgodnie z zasadą należytej legislacji tekst prawny powinna cechować zakładana precyzja (jednoznaczność, określoność), zrozumiałość (komunikatywność) oraz adekwatność w stosunku do intencji prawodawcy. Takie właściwości komunikatu formułowanego $\mathrm{W}$ 10 
oficjalnej odmianie polszczyzny są pożądane zarówno $\mathrm{z}$ punktu widzenia prawnego, jak i językowego. Jak już powiedziano, wchodzą one w skład wzorca normatywnego należytej legislacji. Stanowią także wyznaczniki komunikatywnego stylu (Wolański 2006: 1).

Jasność powinna polegać na tym, że tekst prawny jest czytelny dla adresatów, którzy mają prawo oczekiwać od racjonalnego ustawodawcy tworzenia norm prawnych niebudzących wątpliwości co do treści nakładanych obowiązków i przyznawanych praw (Wyrok TK z 11 grudnia 2009 r., Kp 8/09)². Dzięki temu treść przepisów prawnych ma być czytelna dla adresata, rozumianego jako każdy podmiot prawa, a co najmniej odbiorca normy. W założeniu prawo jest jasne, jeżeli osiągnięta jest precyzja i komunikatywność treści w taki sposób, który pozwala odbiorcy na jego zrozumienie zgodne z intencją nadawcy, a interpretatorowi na osiągnięcie adekwatnego do rozpatrywanego przypadku rezultatu wykładni. Zakładana precyzyjność przepisów jest realizowana poprzez wyrażanie treści przepisów w sposób na tyle określony, aby treść norm prawnych nakładających obowiązki czy przyznających prawa była oczywista dla odbiorcy i umożliwiała ich egzekwowanie (Wyrok TK z 21 marca 2001 r., K.24/00). Z kolei wymagana komunikatywność jest cechą, do której osiągnięcia niezbędne jest takie redagowanie tekstu prawnego, aby był zrozumiały „dla jego przeciętnego adresata”. Nie chodzi jednak o jakąkolwiek czytelność komunikatu, ale o zdolność zrekonstruowania treści normatywnej z przepisów, czyli odtworzenie zakresu zastosowania i zakresu normowania normy prawnej. Wymaga to wiedzy o kodowaniu i dekodowaniu norm (Wronkowska 2007: 18). Odczytany ze zrozumieniem tekst prawny ma być dla odbiorcy komunikatywny w taki sposób, aby było jasne, jakiego zachowania lub powstrzymania się od działania prawodawca od niego oczekuje. Należy zatem formułować przepisy w sposób, w jaki opisuje się typowe sytuacje występujące w regulowanej dziedzinie (§ 5 ZTP). Dyrektywy techniki prawodawczej nakazują redaktorowi tekstu prawnego posługiwanie się poprawnymi wyrażeniami językowymi (określeniami) w ich podstawowym i powszechnie przyjętym znaczeniu ( 88 ust. 1 ZTP).

2 Zob. także: Proces prawotwórczy w świetle orzecznictwa Trybunału Konstytucyjnego. Wypowiedzi Trybunału Konstytucyjnego dotyczące zagadnień związanych $\mathrm{z}$ procesem legislacyjnym, Warszawa 2015, http://trybunal.gov.pl/fileadmin/content/dokumenty/proces_prawotworczy.pdf. 
Tym samym wskazane jest unikanie posługiwania się określeniami specjalistycznymi, o ile ich użycie nie jest powodowane zapewnieniem należytej precyzji tekstu, określeniami lub zapożyczeniami obcojęzycznymi, chyba że nie mają dokładnego odpowiednika w języku polskim oraz nowo tworzonymi pojęciami lub strukturami językowymi, chyba że w dotychczasowym słownictwie polskim brak jest odpowiedniego określenia ( 88 ust. 2 ZTP).

Jak już wspomniano, każda z wymaganych właściwości tekstu prawnego ma uzasadnienie aksjologiczne. Precyzja języka prawnego jest podstawowym warunkiem zapewnienia obywatelom ochrony prawnej i pewności prawa (Mattila 2006: 65). Pozwala na osiąganie przewidywalności prawa. Zrozumiałość treści przekazywanych w tekście prawnym, podobnie jak ich dostępność, wpływa na akceptowalność regulacji prawnych przez adresatów, przesądza także o jakości prawa (Wronkowska 1976: 14). Komunikatywność umożliwia adresatom prawa zapoznanie się z normami prawnymi, które mają obowiązek realizować, natomiast adekwatność pozwala zakładać, że treść norm prawnych jest wyznaczona przez prawodawcę (Ibidem: 19). Celem prawodawcy ma być tworzenie takiego prawa, które będzie realizowało wartości akceptowane $\mathrm{w}$ państwie prawa. Formalne i techniczne działania prawodawcy, w tym także realizowanie wymogu jasności są uwarunkowane etycznie.

\section{Dlaczego jasność jest problematyczna?}

Lon L. Fuller zauważał, że ze względu na fakt, iż oczywisty wymóg nakazujący prawodawcy tworzenie jasnych przepisów dotyczy cechy stopniowalnej i skomplikowanej w zdefiniowaniu (nie dla każdego odbiorcy ten sam komunikat jest w równym stopniu jasny), ale przede wszystkim trudnej do osiągnięcia. Problemy z jasnością mają wielorakie przyczyny, zarówno o charakterze językowym, prawnym, jak i pragmatycznym.

Należy dodać, że nie w każdej sytuacji brak jasności wypowiedzi prawnych jest uchybieniem wymogowi jednoznaczności. W tekstach prawnych występują zwroty, których brak precyzji jest zamierzony przez prawodawcę, jak np. klauzule generalne (jak 
„należyta staranność”, „zasady prawidłowej gospodarki”). W takich przypadkach prawodawca celowo odwołuje się do kontekstu języka powszechnego. Nierzadko to właśnie język potoczny może być narzędziem przekazywania intencji prawodawcy, a skutecznym sposobem na osiągnięcie jasności jest wykorzystanie takich sposobów rozumienia ocen, które ukształtowały się w doświadczeniu pozaprawnym, potocznym (Fuller 20014: 54). Zabiegi takie służą osiąganiu innej ważnej cechy tekstu prawnego, jaką jest elastyczność.

Wzorzec jasności wpisany w zasadę państwa prawnego i opartą na etyce dyskursu komunikację jest założeniem idealistycznym, co czyni go trudnym do osiągnięcia, a nawet niewykonalnym. Wymaganie jednoznaczności tekstu prawnego $\mathrm{w}$ praktyce nie jest spełnione całkowicie, a jedynie w pewnym stopniu (Gizbert-Studnicki 1986: 108). Poniżej zajmujemy się postulatem jasności przepisów prawa oraz próbą zdiagnozowania przyczyn, z powodu których jest on trudno osiągalny.

\subsection{Problem języka - wieloznaczność}

Powód postulatywnego charakteru jasności może być stricte językowy. Dotyczy właściwości typowych dla języka naturalnego przejętych przez język prawny, będący specyficznym rejestrem, ale opartym na zasobie semantycznym, leksykalnym i składniowym polszczyzny ogólnej. Język prawny bazuje na języku powszechnej komunikacji, jest zatem oczywiste, że przejmuje wiele jego cech, do których należy wieloznaczność, niedookreśloność pojęciowa i zakresowa wyrażeń. Zasadniczo od takiego sposobu wypowiedzi oczekuje się precyzji i określoności. Jednak w tekstach prawnych występują wyrazy o zmiennym znaczeniu, wyrażenia nieostre, a także wiele odmian wieloznaczności, jak homonimia, polisemia, okazjonalność (Malinowski 2006: 142 i n.). Przypomnijmy, że wyróżnia się dwa rodzaje wieloznaczności - polisemiczną, kiedy wyraz ma więcej niż jedno znaczenie $i$ znaczenia te są powiązane i homonimiczną, w przypadku której wyraz ma różne znaczenia nie powiązane ze sobą (Zieliński 2002: 141 i n.). W koncepcji Herberta L. A. Harta otwartość semantyczna tekstu prawnego, określana jako open 
texture (Hart 1998: 176 i n.), polega na występowaniu podczas rozumienia niejednoznacznego pojęcia trzech stref - strefy pewności pozytywnej, pewności negatywnej oraz strefy niepewności, tzw. „półcienia niepewności” (penumbra of certainty). Wiele wyrażeń i zwrotów (w szczególności tych, które nie posiadają jednoznacznego sposobu rozumienia $w$ ramach danego języka) ma charakter wieloznaczny i potencjalnie nieostry (niedookreślony zakresowo), co Hart określa jako nieredukowalna otwartość (Ibidem). Interpretacja takich zwrotów polega na wyznaczaniu trzech zakresów odniesienia słów do ich desygnatów. Podczas interpretacji tekstu prawnego następuje „domknięcie” tych wieloznacznych sformułowań w celu ustalenia ich znaczenia, co wymaga odwoływania się do kryteriów pozajęzykowych, a nierzadko dokonywania wyborów aksjologicznych i ważenia zasad. Wieloznaczność, ale też wielość konotacji w języku może być źródłem komplikacji zarówno w interpretacji i stosowaniu prawa, jak też w praktyce translacji tekstów prawnych, szczególnie w sferze prawa Unii Europejskiej. Wynik przekładu jest kompromisem w wyborze spośród kilku znaczeń tego, które tłumacz uznaje za najwłaściwsze w danym kontekście (Mattila 2006: 64).

Sposobem na osiąganie precyzji jest eliminowanie wieloznaczności, niedookreśloności pojęciowych i nieostrości, do czego służy między innymi formułowanie definicji (Ajdukiewicz 1974: 63), w tekstach prawnych definicji legalnych. Z prawnego punktu widzenia ich formułowanie jest uzasadnione, kiedy dane określenie jest wieloznaczne, nieostre, a jest pożądane ograniczenie jego nieostrości, w sytuacji gdy znaczenie danego określenia nie jest powszechnie zrozumiałe oraz gdy ze względu na dziedzinę regulowanych spraw istnieje potrzeba ustalenia nowego znaczenia danego określenia ( $\$ 146$ ust. 1 ZTP). Jednak zadanie prawodawcy polegające na sformułowaniu poprawnej legislacyjnie $\mathrm{i}$ użytecznej w stosowaniu prawa definicji legalnej jest znacznie utrudnione przez wymóg jednoczesnego zrealizowania wielu innych idealistycznych warunków dotyczących pożądanych cech tekstu prawnego (Andruszkiewicz i KosielińskaGrabowska 2007: 35).

Innym znanym sposobem na dążenie do precyzji jest unikanie stosowania $w$ tekstach prawnych synonimów i homonimów. W regulacjach normatywnych znalazło to odzwierciedlenie w zasadzie, zgodnie z którą do oznaczenia jednakowych pojęć używa się 
jednakowych określeń, a różnych pojęć nie oznacza się tymi samymi określeniami (§ 10 ZTP). Wprawdzie w wyniku tego zabiegu pojawiają się $\mathrm{W}$ tekstach prawnych wielokrotne powtórzenia $\mathrm{w}$ bliskim sąsiedztwie tych samych wyrazów, co może być odnotowywane jako odstępstwo od normy językowej w zakresie stylistyki, jednak występowanie w języku prawnym synonimów mogłoby być przyczyną wątpliwości semantycznych i trudności $w$ ustaleniu, czy dane określenie ma odniesienie do tego, czy innego pojęcia (Weston 1991: 32-22). Stąd też uważa się, że ich unikanie ma ułatwiać osiągnięcie zrozumiałości i usprawniać wykładnię. Faktem jest, że obecność wyrazów przenikających się $w$ zakresach semantycznych jest rezultatem tendencji rozwojowych słownictwa, zanikania pewnych wyrazów i powstawania nowych, przyswajania do zasobu leksykalnego wyrazów obcych. Jest to uwarunkowane zróżnicowaniem języka na odmiany, co powoduje tendencję specjalizacji znaczeniowej, zakresowej i stylistycznej synonimów (Kurkowska, Skorupka 2001: 149). Nie zawsze możliwe jest całkowite wyeliminowanie $\mathrm{z}$ tekstów prawnych wyrazów, których zakresy znaczeniowe się przenikają, zwłaszcza na poziomie uniwersalnego języka prawnego. W przypadku synonimów, podobnie jak przy problemach z wieloznacznością, język prawny jest również „naznaczony” właściwościami języka ogólnego.

\subsection{Problem nadawcy - trudno definiowalna intencja}

Oczekiwanie spełnienia wymogu określoności treści prawa dotyczy także nierozmijania się jej skutków z rzeczywistymi intencjami prawodawcy (zob. wyrok TK z 31 marca 2005 r., sygn. SK 26/02, OTK ZU nr 3/A/2005, poz. 29). Tekst prawny jako szczególny rodzaj komunikatu normatywnego jest tworzony przez nadawcę, który jest utożsamiany $\mathrm{z}$ konwencjonalną kategorią prawodawcy. Jest on wyposażony w zakładaną racjonalność (Sarkowicz 1995: 31 i n.). Przypomnijmy, że w uproszczonym ujęciu konstrukcja racjonalnego prawodawcy jest założeniem pozwalającym przypisać mu idealną kompetencję językową, kompletną znajomość dyrektyw techniki prawodawczej, pełną wiedzę o przedmiocie regulacji itd. Racjonalność 
jest zakładaną właściwością nadawcy komunikatu prawnego, stanowi idealizacyjną i kontrfaktyczną konstrukcję.

Od prawodawcy oczekuje się, aby prawidłowo, tj. zgodnie z wymogami należytej legislacji, sformułowany tekst prawny był instrumentem prawa, które ma być pewne i przewidywalne. Jak wskazywał Trybunał Konstytucyjny, formułowanie przepisów ustawy w taki sposób, że użyte pojęcia byłyby sprzeczne bądź dawały powód do dowolności interpretacji, jest naruszeniem zasady ochrony zaufania do państwa i stanowionego przez nie prawa (Wyroki TK z 22 maja 2002 r., K 6/02, 8 grudnia 2009 r., K 7/08). Przewidywalność jest zagrożona w przypadku występowania zwrotów niedookreślonych, których znaczenie zależy od elementów subiektywnych, bądź też zwroty takie mają brzmienie uniemożliwiające jednolite stosowanie i utrudniają interpretację. Pomimo to, $w$ tekstach prawnych występują zwroty i pojęcia, których zrozumienie budzi wątpliwości ze względu na rozbieżność systemów wartości, do których odwoływanie się jest potrzebne przy ustalaniu znaczenia. Obowiązkiem interpretatora jest ustalenie takiego znaczenia tekstu prawnego, które jest zgodne $\mathrm{z}$ intencją prawodawcy. Zrozumiałość wymagana jest $\mathrm{w}$ odniesieniu do reguł języka ogólnego, uznawanego za powszechnie zrozumiały. Jednak nie chodzi tutaj ani o zrozumiałość w sensie szerokim (w jakikolwiek sposób), ani o zrozumiałość powszechną (dla każdego w każdej sytuacji komunikatywnej). Odczytanie tekstu prawnego jako zrozumiałego dotyczy jego rozumienia w sposób, jaki chciał jego odczytania prawodawca. Wypowiedź prawodawcy może być zrozumiana, ale też zrozumiana niewłaściwie bądź niezrozumiana. Rozumienie tekstu prawnego w sposób określany jako wzorcowy to takie rozumienie, które odpowiada powszechnym regułom interpretacyjnym (Gizbert-Studnicki 1986: 118). Wiadome jest, że w praktyce wykładniczej proces dekodowania treści norm prawnych z przepisów jest dokonywany nie przez każdy podmiot prawa, obywatela, ale prawników profesjonalistów, którzy pośredniczą w odbiorze treści prawa. Prawodawca nakazuje organom stosującym prawo informowanie i udzielanie wyjaśnień stronom $\mathrm{w}$ toku postępowania oraz $\mathrm{w}$ uzasadnieniach orzeczeń, przekonując tym samym, iż oryginalne teksty prawne są źródłem informacji głównie dla podmiotów pośredniczących w rozumieniu prawa (Gizbert-Studnicki 1986: 129). Sama intencja może być trudna do zrekonstruowania ze 
względu na fakt, iż nadawca nie jest podmiotem indywidualnym wyposażonym w określoną intencję, a podmiotem zbiorowym, tworem konwencjonalnym. Intencja nadawcy nie jest wyrażana wprost, co wynika ze specyfiki sytuacji socjolingwistycznej języka prawnego, w której nadawca i odbiorca pozostają w relacji niebezpośredniej i formalnej (Gizbert-Studnicki, 1986: 49 i n.). Poza tym, zrekonstruowanie intencji prawodawcy może być skomplikowane ze względu na trudność $\mathrm{w}$ ustaleniu, która $\mathrm{z}$ intencji którego prawodawcy - realnego, idealnego, wyższego czy niższego hierarchicznie ma być odtworzona (Matczak 2007: 176).

Dodać należy, że brak precyzji w tekstach prawnych może być wynikiem swego rodzaju niedookreśloności intencji prawodawcy w sytuacji, kiedy z powodu niemożności przewidzenia wszystkich stanów faktycznych, które mogą być objęte zakresem regulacji prawnej nieprecyzyjnie sformułowany tekst prawny zwiera zamierzony luz decyzyjny (Gizbert-Studnicki 1986: 108). W takim przypadku nadawca komunikatu prawnego intencjonalnie pozostawia jego doprecyzowanie organowi stosującemu prawo, a niecałkowita jasność nie stanowi mankamentu tekstu prawnego.

\subsection{Problem interpretatora - permanentna niejasność}

Trudność w zaakceptowaniu tezy, że osiągnięcie pełnej jasności w tekście prawnym jest możliwe powodowana jest zmiennością znaczeń $\mathrm{w}$ czasie oraz różnic $\mathrm{w}$ znaczeniu nadanym w czasie jego uchwalania oraz w czasie, w którym jest interpretowany (Matczak 2007: 158). W danej sytuacji interpretacyjnej może wystąpić zderzenie kilku lub więcej wersji znaczenia nadanego przez wielu prawodawców realnych. Powiedziano już, że znaczenie to ma zostać uzgodnione $\mathrm{w}$ taki sposób, aby odzwierciedlało intencję prawodawcy, ale właśnie realnego, a nie formalnego. Problem polega na tym, że w takim przypadku nie chodzi o dosłownie rozumiany brak jasności, ale potrzebę wyważenia znaczenia, dokonania wyboru tego, które odzwierciedla znaczenie właściwe dla rozstrzyganego przypadku. Podczas ustalania znaczenia może wystąpić sytuacja, w której interpretator stoi przed zadaniem uwzględnienia jednocześnie kilku 
komunikatów, z których każdy cechuje się jasnością (Brożek 2006: 87). Powoduje to, że nie tylko nie mamy do czynienia z jasnością, ale wręcz odwrotnie, jak stwierdza Marcin Matczak, permanentną niejasnością tekstu prawnego (2007: 175).

Wymienione problemy $\mathrm{z}$ jasnością przekonują, iż do odczytania sensu znaczeniowego wypowiedzi prawodawcy wykorzystywane jest idealizacyjne założenie nie tylko dotyczące prawodawcy, ale i odbiorcy tekstu prawnego. Do właściwego rozumienia tekstów prawnych wymagana jest kompetencja językowa i komunikacyjna użytkownika języka. Niezbędna jest specjalistyczna umiejętność konstruowania norm $\mathrm{z}$ przepisów prawnych oraz znajomość reguł wykładni sensu stricto w zakresie eliminowania wieloznaczności i nieostrości znaczeniowej wyrazów i zwrotów, znajomość reguł inferencyjnych, umożliwiających wyprowadzanie $\mathrm{z}$ tekstu konsekwencji norm wysłowionych wprost $\mathrm{w}$ postaci norm pośrednich, i wreszcie umiejętność wykorzystania w wykładni reguł drugiego stopnia (dyrektyw preferencji) w sytuacji, gdy reguly sensu stricto nie są spójne (Gizbert-Studnicki 1986: 110 i n.). Na podstawie tych warunków można zrekonstruować wizję doskonałego odbiorcy tekstów prawnych, któremu przypisuje się zakładaną kompetencję komunikacyjną, właściwą odbiorcy idealnemu, co pozwala sądzić, że na językowy kształt prawa wpływa też kontekst społeczny, a pojęcie doskonałego odbiorcy ma charakter wartościujący (Ibidem: 114-115). Przypisuje się mu umiejętność dokonywania wyboru tego znaczenia, za którym przemawia określony system wartości. Znaczenie tekstu prawnego może być uwarunkowane czynnikami kontekstowymi, kulturowymi, zwłaszcza podczas dokonywania wykładni celowościowej. Interpretator występuje w roli odbiorcy pośredniczącego $\mathrm{W}$ percepcji treści prawa. Nawiasem mówiąc, językoznawcy i thumacze tekstów ze sfery prawnej również podkreślają, że jasności i zrozumiałości należałoby oczekiwać nie tyle od języka prawnego, który jest poddawany wyjaśnianiu przez specjalistów z zakresu prawa, ile od języka prawniczego, którym posługują się $\mathrm{W}$ obrocie prawnym nie tylko profesjonaliści pośredniczący $\mathrm{w}$ odbiorze, ale obywatele $\mathrm{i}$ inne podmioty prawa nie posiadający wiedzy prawniczej, a będący adresatami wyjaśnianych tekstów prawnych (Matulewska 2016). 
Należy podkreślić, że postulat dążenia do całkowitej jasności jest charakterystyczny dla formalistycznego podejścia do prawa i jego interpretacji, zakładającego, że możliwe jest odkrywanie podczas wykładni takiego znaczenia, które, adaptując terminologię Stanleya Fisha, można określić jako zwykłe, normalne czy dosłowne (2002: 29). Jednoznaczność podczas wykładni jest osiągana nie tylko ze względu na cechy samego języka, ale kontekst, sytuację odczytania sensu, który w różnych aktach interpretacji może być różny i dawać odmienne rezultaty wykładnicze, właśnie w zależności od uwarunkowań kontekstowych i sytuacyjnych.

\subsection{Problem sprzeczności i asymptotyczności postulatów jasności}

Jak już powiedziano, podczas redagowania tekstu prawnego konieczne jest pogodzenie dwóch wymogów - jednoznaczności (dążenia do precyzji) i komunikatywności (zrozumiałości). Jednoznaczność jest trudna do osiągnięcia przy jednoczesnym wymogu komunikatywności. W przypadku jasności mamy do czynienia z pewną oczywistością, będącą jednocześnie źródłem komplikacji, jaką jest asymptotyczny charakter tych postulatów. Nie zawsze są osiągalne, a nawet można uznać je za sprzeczne (Gizbert-Studnicki 1986: 103104). Jasność możliwa jest dzięki precyzji, natomiast zrozumiałości towarzyszy często brak zwięzłości czy redundancje leksykalne (Ibidem). Tekst, jasny rozumiany jako jednoznaczny powinien zawierać zwroty precyzyjnie definiowane, co może skutkować hermetycznością znaczeń, wprowadzaniem zwrotów specjalistycznych, profesjonalizmów, których znaczenie odbiega od znaczenia powszechnego. Z kolei tekst jasny jako zrozumiały powinien być wyposażony $\mathrm{w}$ wyjaśnienia, omówienia, przykłady, co $\mathrm{w}$ tekście prawnym jest niepożądane (Zob. np. § 11 ZTP). Służy temu zasada nadawania wyrazom i zwrotom ich podstawowego, powszechnie przyjętego znaczenia ( $\S 8$ ust. 1 ZTP). Tak sformułowany tekst zawierający treść normatywną wymaga wyważenia obu pożądanych cech, co sprawia, że regulacje prawne są wypadkową zarówno jasności, jak i zrozumiałości (Jaskiernia 1999: 86). Można zatem mówić nie tyle o jednoczesnym spełnieniu tych dwóch wymogów, ile uznawaniu 
pierwszeństwa jednego $\mathrm{z}$ nich, kiedy zachodzą między nimi sprzeczności. W doktrynie i praktyce prawniczej przyjmuje się, że konstytucyjna zasada określoności przepisów prawa ma charakter bezwzględny, ale jej charakter wiążący może być zróżnicowany w zależności od regulowanej materii. W sytuacji kiedy prawodawca jest zmuszony do dokonania wyboru pomiędzy komunikatywnością a jednoznacznością, powinien przyznać pierwszeństwo jednoznaczności, głównie ze względu na potrzebę osiągania pewności prawa (Wronkowska 1976: 26). W tym przypadku, jak i w wyżej omówionych aspektach „niejasności” tekstów prawnych okazuje się, że nacechowanie aksjologiczne determinuje sposób rozwiązania problemów technicznych w redagowaniu tekstu prawnego. Postulat jasności jest wymogiem formalnoprawnym, ale jego osiągnięcie zależy od czynników pozaprawnych - kontekstowych i etycznych.

\subsection{Problem niedostatecznej kompetencji komunikacyjnej}

Innym, nie mniej ważnym, powodem nieosiągalności jasności może być niedoskonałość wytworów prawodawcy i tworzenie przepisów, które powodują trudności interpretacyjne na skutek zaniedbań w zakresie poprawności językowej czy niedostatecznej kompetencji komunikacyjnej nadawcy. Wymienione wyżej problemy z ustaleniem intencji prawodawcy, właściwego znaczenia pojęć języka prawnego czy bezkolizyjnej interpretacji mogą być spotęgowane w sytuacji, gdy wprowadzaniu nowych regulacji prawnych nie towarzyszy dokonana na etapie prelegislacyjnym wnikliwa diagnoza dotycząca przedmiotu regulacji, sytuacji prawnej, społecznej, wykorzystywanie opinii Rady Legislacyjnej, sporządzanie uzasadnień proponowanych regulacji itd. Autorzy komentarzy do ZTP podkreślają, że chociaż wskazania tam zawarte nierzadko formułowane są w sposób kategoryczny, to jednak w praktyce prawodawczej wiele z nich jest ignorowanych (Warylewski 2003: 489). Normatywny wzorzec stanowi prakseologiczny kanon, który powinien być respektowany przez ustawodawcę w państwie prawa (Zob. np. Wyrok TK z 21 marca 2001 r., K.24/00). Ich zasadniczo wiążący charakter odnosi się do strony technicznej tekstu prawnego. Ich naruszenie przez redaktora skutkuje 20 
wadliwością konstrukcyjną, a nie walidacyjną, tj. tekst może być uznany za niepoprawny pod względem redakcyjnym, ale nie jest nieobowiązujący w sensie prawnym (Wronkowska, Zieliński, 2004: 20). Brak sankcji za nieprawidłowo redagowane teksty prawne osłabia realny wpływ zasad techniki prawodawczej na działania legislatorów. Pomimo, iż regulacje normatywne ZTP mają charakter lex imperfecta, ich złamanie może być uznane za naruszenie zasady państwa prawa, jeżeli polega na rażącej niejasności przepisów. Naruszenie zasady określoności w zakresie ustawowej ingerencji w sferę konstytucyjnych praw i wolności jednostki może być uznane za samoistną przesłankę stwierdzenia naruszenia art. 2, a także art. 31 ust. 3 Konstytucji RP, tj. niekonstytucyjności regulacji (Wyrok TK z 12 grudnia 2004 r., K 32/04, OTK ZU 2005, seria A, nr 11, poz. 132).

Nawiasem mówiąc, poza tego rodzaju niedoskonałościami czy wręcz uchybieniem zasadzie poprawnej legislacji, wymóg jasności stawia redaktora tekstu prawnego przed wyzwaniem ze względu na wymogi normy językowej. Z punktu widzenia językoznawczego restrykcyjne dążenie do precyzji może prowadzić do naruszenia norm prawności językowej, niedoskonałości stylistycznych, składniowych, a nawet zakłócenia zrozumiałości wypowiedzi (Malinowska 1999: 87 i n., Pawelec 2007: 68). Językoznawcy zwracają uwagę na występujące w tekstach prawnych niedoskonałości odbiegające od ideału komunikacyjnego i poprawnościowego. Zauważane jest nadużywanie rozbudowanych struktur zdaniowych, nominalizacji, imiesłowów, konstrukcji dzierżawczych (Kaczmarek 2015: 64). Należy zauważyć, ze naruszenie reguł językowych nie zawsze jednak oznacza niepoprawność w tekście prawnym. Redaktor tekstu prawnego realizuje wymóg osiągania zwięzłości, czego przykładem jest zasada jednozdaniowości jednostki redakcyjnej. Wymóg formułowania jednostek redakcyjnych aktu normatywnego nakazuje każdą samodzielną myśl ujmować się w odrębny artykuł, przy czym artykuł powinien być w miarę możliwości jednozdaniowy (§ 55 ust. 1, 2 ZTP). Wprowadza się jednak w obrębie artykułu następną jednostkę redakcyjną (ustęp) jeżeli samodzielną myśl wyraża zespół zdań, a także w przypadku, gdy między zdaniami wyrażającymi samodzielne myśli występują powiązania treściowe, ale treść żadnego $\mathrm{z}$ nich nie jest na tyle istotna, aby wydzielić ją w odrębny artykuł (§ 55 ust. 3, 4 ZTP). Powoduje to nierzadko konieczność używania zdań wielokrotnie 
złożonych, zawierających wydzieloną samodzielną treść, która powinna znaleźć się w obrębie jednej jednostki redakcyjnej, mimo, iż zgodnie $\mathrm{z}$ dyrektywami techniki prawodawczej należy unikać w języku prawnym zdań wielokrotnie złożonych (§ 7 ZTP). Precyzyjne wyrażenie zamysłu prawodawcy wymaga powtórzenia $\mathrm{w}$ strukturze zdaniowej tej samej formy wyrazowej, co z językoznawczego punktu widzenia może budzić zastrzeżenia stylistyczne. W tekście prawnym uwzględniane są specyficzne dla kodowania norm reguły kondensacji i rozczłonkowania treści. Powoduje to trudności w osiąganiu idealistycznego wzorca poprawności językowej.

\section{Konkluzja}

Wymóg określoności przepisów prawa ma charakter postulatywny i stopniowalny. Osiągnięcie całkowitej jasności jest problematyczne z kilku powodów. Po pierwsze, jednoznaczność jest uniemożliwiona $\mathrm{w}$ sytuacji występowania wyrażeń $\mathrm{i}$ zwrotów otwartotekstowych i niedookreślonych. W rejestrze języka naturalnego, jakim jest język prawny jako odmiana języka etnicznego, jest niemożliwe osiągnięcie $\mathrm{w}$ takich przypadkach całkowitej jasności. Po drugie, ustalanie znaczenia tekstu prawnego opiera się na konieczności zrekonstruowania intencji prawodawcy, która może być trudna do ustalenia z powodu złożoności i specyfiki tej instancji nadawczej. Po trzecie, problem odbiorcy - interpretatora w ustaleniu właściwego znaczenia normy może wynikać $\mathrm{z}$ rozbieżności znaczeń alternatywnych w danej sytuacji interpretacyjnej, jak również konieczności dokonywania podczas wykładni wyborów aksjologicznych. Po czwarte, postulaty języka prawnego mają charakter asymptotyczny, czy wręcz pozostają we wzajemnej sprzeczności. Możliwe jest zatem jedynie osiąganie pewnego stopnia precyzji lub komunikatywności, bądź przedkładanie jednej cechy przed drugą (np. jednoznaczność kosztem zrozumiałości). I wreszcie, trudność w zrealizowaniu postulatu jasności może wynikać z problemu kompetencji językowej i komunikacyjnej redaktorów tekstów prawnych, którzy nierzadko nie traktują wskazań prawidłowej techniki legislacyjnej jako priorytetowych, a nawet je ignorują. Powodem komplikacji jest też nie 22 
zawsze możliwe pogodzenie wymagań wynikających $\mathrm{z}$ normy językowej i formalnoprawnych oczekiwań dotyczących poprawności. Wymóg jasności, choć postulatywny, pozostaje składnikiem kanonu dobrego prawa. Nie tyle ze względu na oczekiwanie, że prawodawca w treści przepisów zawrze jednoznaczne rozwiązanie każdej sytuacji kwalifikowanej prawnie (co nie jest wykonalne, ilekroć występują hard cases), ile urzeczywistnienie zasady, że na każdym etapie prawotwórczym będą realizowane założenia nie tylko proceduralne, ale aksjologiczne i etyczne. Tak tworzone prawo będzie zasługiwało na miano ius est ars boni et aequi - sztuki czynienia tego, co dobre i słuszne.

\section{Bibliografia}

Ajdukiewicz, Kazimierz. 1974. Logika pragmatyczna. Warszawa: Państwowe Wydawnictwo Naukowe.

Andruszkiewicz, Marta, i Urszula Kosielińska-Grabowska. 2007. Prawodawca w labiryncie definicji legalnej. Studia PrawnoEkonomiczne LXXV: 9-36.

Andruszkiewicz, Marta. 2016. Jasność językowa w kontekście prawa do należytej legislacji. W Prawa jednostki $w$ demokratycznym państwie prawa. Zagadnienia wybrane, red. Adam Jamróz i Lech Jamróz, 177-188. Białystok: Temida 2.

Brożek, Bartosz. 2006. Derywacyjna koncepcja wykładni z perspektywy logicznej. Ruch Prawniczy, Ekonomiczny i Socjologiczny 1: 81-92.

Fish, Stanley. 2002. Zwykłe okoliczności, język dosłowny, bezpośrednie akty mowy, to, co normalne, potoczne, oczywiste, zrozumiałe samo przez się i inne szczególne przypadki. W Interpretacja, retoryka, polityka. Eseje wybrane, red. Andrzej Szahaj, 29-58. Kraków: Universitas.

Fuller, Lon L. 2004. Moralność prawa. Tłum. Stefan Amsterdamski. Warszawa: Dom wydawniczy ABC.

Gizbert-Studnicki, Tomasz. 1986. Język prawny z perspektywy socjolingwistycznej. Zeszyty Naukowe Uniwersytetu Jagiellońskiego. Prace z nauk politycznych 22. 
Hart Herbert L.A. 1998. Pojęcie prawa. Tłum. Jan Woleński. Warszawa: Wydawnictwo Naukowe PWN.

Jaskiernia, Jerzy. 1999. Zasady demokratycznego państwa prawnego w sejmowym postępowaniu ustawodawczym, Warszawa: Wydawnictwo Sejmowe.

Kaczmarek, Karolina. 2015. Komunikatywność węgierskich i polskich tekstów prawnych i prawniczych. W Język polskiego prawa: perspektywa europejska, red. Dorota Kondratczyk-Przybylska, Adam Niewiadomski i Ewa Walewska. 58-63. Warszawa: Zakład graficzny Uniwersytetu Warszawskiego.

Proces prawotwórczy $w$ świetle orzecznictwa Trybunatu Konstytucyjnego. Wypowiedzi Trybunatu Konstytucyjnego dotyczace zagadnień zwiazanych z procesem legislacyjnym. http://trybunal.gov.pl/fileadmin/content/dokumenty/proces_pr awotworczy.pdf (data dostępu 20 września 2016).

Kurkowska, Halina, i Stanisław Skorupka. 2001. Stylistyka polska. Zarys. Warszawa: Wydawnictwo Naukowe PWN.

Malinowska, Ewa. 1999. Język w urzędach. W Polszczyzna 2000. Orędzie o stanie języka na przetomie tysiacleci, red. Walery Pisarek, 75-96. Kraków: Ośrodek Badań prasoznawczych. Uniwersytet Jagielloński.

Malinowski, Andrzej. 2006. Polski język prawny. Wybrane zagadnienia. Warszawa: Wydawnictwo Prawnicze LexisNexis.

Matczak, Marcin. 2007. Summa iniuria. O błędzie formalizmu w stosowaniu prawa. Warszawa: Wydawnictwo Naukowe Scholar.

Mattila, Heikki E.S. 2006. Comparative Legal Linguistics. Hampshire: Ashgate.

Matulewska, Aleksandra. 2016. W labiryncie intra- i interlingwalnej komunikacji prawnej i prawniczej. Referat wygłoszony na Kongresie Języka Prawnego i Prawniczego i X Konferencji Lingua Iuris, 21-22 kwietnia w Warszawie.

Pawelec, Radosław. 2007. O poprawności językowej i zrozumiałości tekstów prawnych i prawniczych. W Język polskiej legislacji, czyli zrozumiatość przekazu a stosowanie prawa. Materiaty z konferencji zorganizowanej przez Komisje Kultury i Środków 
Przekazu oraz Komisje Ustawodawcza Senatu RP, 65-70. Warszawa: Kancelaria Senatu RP.

Proces prawotwórczy $w$ świetle orzecznictwa Trybunatu Konstytucyjnego. Wypowiedzi Trybunatu Konstytucyjnego dotyczace zagadnień zwiazanych z procesem legislacyjnym. http://trybunal.gov.pl/fileadmin/content/dokumenty/proces_pr awotworczy.pdf (data dostępu 20 września 2016).

Sarkowicz, Ryszard.1995. Poziomowa interpretacja tekstu prawnego. Kraków: Uniwersytet Jagielloński.

Stownik języka polskiego. http://sjp.pwn.pl/szukaj/jasność.html (data dostępu 20 września 2016).

Szymczak, Mieczysław, red. 1978. Słownik języka polskiego t. I. Warszawa: Państwowe Wydawnictwo Naukowe.

Warylewski Jarosław, red. 2003. Zasady techniki prawodawczej. Komentarz do rozporzadzenia. Warszawa: Wolters Kluwer Polska SA.

Weston, Martin. 1991. An English Reader's Guide to the French Legal System, New York/Oxford: Berg.

Wolański, Adam. 2006. Siedem kanonów stylu komunikatywnego, czyli jak pisać, by czytano nas chętnie i powszechnie. W Polszczyzna na co dzień, red. Mirosław Bańko,1-33. Warszawa.

Wronkowska, Sławomira. 1976. Postulat jasności prawa i niektóre metody jego realizacji. Państwo i Prawo 10.

Wronkowska, Sławomira. 2007. O cechach języka tekstów prawnych.

W Język polskiej legislacji, czyli zrozumiałość przekazu a stosowanie prawa. Materiaty z konferencji zorganizowanej przez Komisję Kultury i Środków Przekazu oraz Komisję Ustawodawcza Senatu RP, 15-25. Warszawa: Kancelaria Senatu RP.

Wronkowska, Sławomira, i Maciej Zieliński. 2004. Komentarz do zasad techniki prawodawczej. Warszawa: Wydawnictwo Sejmowe.

Zieliński, Maciej. 2002. Wykładnia prawa. Zasady, reguły, wskazówki. Warszawa: Wydawnictwo Prawnicze LexisNexis. 